\title{
Histomorphometric Characterization of Forestomach of Yak (Bos grunniens) in the Qinghai-Tibetan Plateau
}

\author{
Caracterización Histomorfométrica del Preestómago del Yak \\ (Bos grunniens) en la Meseta Qinghai-Tíbet
}

Jinbao Wang*; Haiyan Li*; Lu Zhang*; Yuan Zhang*; Mingxia Yue*; Baoping Shao* \& Jianlin Wang*

WANG, J.; LI, H.; ZHANG, L.; ZHANG, Y.; YUE, M.; SHAO, B. \& WANG, J. Histomorphometric Characterization of Forestomach of Yak (Bos grunniens) in the Qinghai-Tibetan Plateau. Int. J. Morphol., 32(3):871-881, 2014.

SUMMARY: Six forestomachs of yaks (Bos grunniens) were studied with gross dissection and histological methods. It was found that the forestomach of yak consisted of the following three parts, rumen, reticulum and omasum, which were composed of the mucosa, submucosa, muscularis and serosa. In addition, the mucosal epithelium was covered with stratified squamous epithelium, with part of keratinized the shallow cells. Rumen, the mucosa of which formed ligulate papillae varying in size and shape, was no muscularis mucosa. Reticulum, consisted of a surface epithelium that invaginated to various extent into the lamina propria, formed various folds in shape, namely, grid-like small rooms. Furthermore, there are many secondary folds densely covered with keratinized papillae. The most striking feature of the omasum was to be formed the laminae omasi varying in length, with short and rough papillae distributing on both sides. Taken together, there was no glands within the mucosa and lamina propria of forestomach of yak, where diffuse lymphoid tissues can be observed clearly. It is, therefore, believed that the yak forestomach may have evolved those specific structural characteristics in response to the unique living environment and dietary habits impose on the Qinghai-Tibetan Plateau.

KEY WORDS: Bos grunniens; Forestomach; Histomorphometric; Qinghai-Tibetan Plateau.

\section{INTRODUCTION}

The yak (Bos grunniens), as a year-round grazing animal, is a key species in the world, living in the QinghaiTibetan Plateau. At present, their total number is about 14 million, which represents more than $90 \%$ of the world yak population. These yaks provide $>90 \%$ of the milk and $50 \%$ of meat consumed by the local herdsmen (Long et al., 1999). They mainly live in alpine grassland in northwestern and southwestern China. Yaks may have acquired many special abilities and attributes to adapt harsh natural environment characterized by high altitude ( $\geq 3,000 \mathrm{~m}$ above sea level), very low annual average temperature, short growing season and great seasonal variation in feed supply.

Ruminant's stomach has developed four separate compartments, each with its own morphological particularities. The first three parts are rumen, reticulum and omasum, commonly known as forestomach (Clauss et al., 2010; Jerbi \& Pérez, 2013). Although there has been considerable researches into the organization of the stomach in cattle (Vivo et al., 1990), sheep (Redondo et al., 1997), deer (Franco et al., 2011, 2012; Redondo et al., 2011), and goat (El-Gendy \& Derbalah, 2010; Garcia et al., 2012), there are few reports on yak's digestion function and corresponding morphology. In this study, we observed morphological structure of the forestomach through method of gross anatomy, and then the histological structure by general staining and special histochemical method, to understand the morphological and physiological function of the yak forestomach better, especially adaption for the balance of whole-body energy homeostasis in short growing season, and to provide a resource for research into metabolism that enable yaks to survive extreme environments in the QinghaiTibetan Plateau, China

\section{MATERIAL AND METHOD}

Animals. All research protocols used in the current experiment were approved by Animal Ethics Committee of the Qinghai province, China. The stomachs of 6 healthy yak (4 castrated and 2 females, 3-4-yr-old) with a mean BW of $255 \mathrm{~kg}( \pm 20 \mathrm{~kg})$ were collected immediately after being slaughtered from Datong slaughter house, Datong county 
( $\geq 3,000 \mathrm{~m}$ above sea level), Qinghai, China. Various parts of the stomachs were fixed with $4 \%$ Paraformaldehyde solution (PH 7.4) after observation of gross anatomy.

Sampling and methods. Surface enlargement factor of rumen mucosa (SEF) was evaluated in this paper. There were many papillae in mucosa wall in rumen, thus expanding absorption area of rumen. The size and density of papillae is not only related with animal species, but also with the availability of food resources and quality, therefore this method can be used to predict and evaluate the nutritional status of ruminants. Hofmann \& Stewart (1972) thought that dorsal wall (DW), ventral wall (VW), cranioventral floor of atrium (ACF) and floor of dorsocaudal blind sac (DBF) of rumen wall reflected the change of diet and nutritional status of ruminants. Above-mentioned 4 areas $(5 \times 5 \mathrm{~cm})$ in the yak rumen were taken, stored in $60 \%$ ethanol, respectively. For laboratory analysis, the dehydrated specimens $(1 \times 2 \mathrm{~cm})$ were taken, then counted the density of papillae under dissecting microscope, and randomly measured the height and width of 20 papillae (be accurated $0.01 \mathrm{~cm}$ ), finally calculated SEF values of 4 sampling areas of rumen by Hofmann formula:

$\mathrm{SEF}=[(\mathrm{NxSA})+\mathrm{BS}] / \mathrm{BS}(\mathrm{SEF}=$ surface enlargement factor; $\mathrm{N}=$ number of papillae; $\mathrm{SA}=$ surface area; $\mathrm{BS}=$ base surface).

Once the forestomach had been separated, small pieces of tissue were dissected for analysis. Tissues for histological examination were fixed in $4 \%$ buffered formaldehyde for 24 hours, after the specimens were dehydrated through a graded series of alcohol, cleared and embedded in paraffin wax, and sectioned at 5-7 $\mu \mathrm{m}$. Sections were stained with hematoxylin-eosin (H-E), Van Gieson, Weigert, Gordon-Sweet and Toluidine blue dye staining.

\section{RESULTS}

Gross anatomy structure. As a large ruminant, the yak's stomach was the essentially same as the camel's (Camelus bacrtrianus), which occupied almost $3 / 4$ of abdominal cavity (Wang et al., 2000). The stomach of the yak consisted of the following four parts, rumen, reticulum, omasum and abomasum. Rumen, which accounted for $75-78 \%$ of the entire stomach, was the largest, following by the abomasum, omasum and reticulum, successively. The first three parts were commonly known as forestomach, which was focused on in this paper.

Rumen. Rumen was shaped like a flattened sac and had a capacity of approximately $42-45 \mathrm{~L}$. There were sulcus cranials and sulcus caudalis in the front and rear end and sulcus ruminis sinster and sulcus ruminis dexter in the left and right side. The backpack and ventral sac around left and right longitudinal groove of the whole rumen were observed. The interface between rumen and reticulum was about 13 $\mathrm{cm}$ in diameter, in which was the vestibular of rumen in shape of pleats, it was the anterior column behind the vestibular.

Most of mucosa covered with dense papillae at the surface, especially abdominal sac, was brown or black. But the edge of adductor muscle was pale, and the mucosa of backpacks sac was gray. The papillae, which gathered into a carpet or brush-like, varied greatly in size and shape, such as flat, ligulate and leafy and so on. The average length and density of papillae was about $0.8-1.0 \mathrm{~cm}$ and $80-100 \mathrm{~cm}^{2}$, respectively. However, the mucosa of adductor muscle and backpack sac that absented of papillae was smooth, then the sidewall of backpack sac only had low and sparse granular papillae.

Reticulum. Reticulum was located in the forefront of rumen. As the smallest part, reticulum was like a pear in shape and had a capacity of 4-7\% the total volume of the yak's stomach. There were great many grids varying in size and shape formed by uplift folds of mucosa, those folds interconnected each other and formed four, five-sided or hexagonal grids, which were about $1.2 \mathrm{~cm}$ high. In addition, many lower secondary folds at the bottom of rooms did the second partition to those grids and formed small irregular grids, at the bottom of which densely covered with horny papillae, as well as on the folds. Moreover, the closer to the edge of pleats between rumen and reticulum, the smaller the rooms were, and even disappearing.

Ostium reticulo-omasicum located in the small bend of reticulum was a circular opening, about $5 \mathrm{~cm}$ in diameter, and had approximately $14-16 \mathrm{~cm}$ above the basal reticulum toward the right side of the body midline. Furthermore, the lip of sulcus reticuli was looked upon as the boundary of the bottom edge of opening and side edge of ostium reticuloomasicum.

Sulcus reticuli, also known as sulcus esophageus, started from the cardia, and downed along the vestibular of rumen and the right side of reticulum wall and connected with omasum ditch when reaching ostium reticuloomasicum. The total length was about $23 \mathrm{~cm}$. Intumescent mucosal folds on both sides of ditch, which was rich in muscle tissue and so called the lip, was more smooth and slightly helical twist.

Omasum. The omasum, lying mainly in the middle right 
side of the abdominal cavity, was oval in shape and had a mean capacity of $4.1 \mathrm{~L}$, about $6-8 \%$ of the total volume of the yak stomach. The oblique wall of omasum located in right front of diaphragmatic liver. Meanwhile, the facies visceralis was contact with reticulum, rumen and abomasum. Fundus of omasum was located in the lesser curvature toward right rear of omasum's bend, and the upper and lower ends of lesser curvature leaded to reticulum and abomasum, respectively. Furthermore, the sulcus omasi was extending along the cavity surface of lesser curvature, where liquid and small particles feed would directly flow into abomasum from reticulum.

Yak's sulcus omasi, which started at reticuloomasal orifice and ended at ostium omasoabomasicum, was approximately $4.5 \mathrm{~cm}$ long. Only some small folds and papillae at bottom of sulcus omasi can be seen obviously, but without laminae omasi. Interestingly, omasum's mucosa in yak was formed over hundreds of laminae omasi that was shaped like a crescent, attaching to the greater curvature of omasum wall and the free edge toward the lesser curvature. Laminae omasi, which neatly and alternately arranged in a regular and divided omasum cavity into many narrow and ordered gap, were classified into 18 pieces of large, $10 \mathrm{~cm}$ wide, 20 pieces of medium, $5 \mathrm{~cm}$ wide, 40 pieces of small, 1 $\mathrm{cm}$ wide, and 60 pieces of linear gaps, $1 \mathrm{~mm}$ wide according to their width.

According to anatomical features, the yak's reticuloomasal orifice was significantly smaller than omasoabomasal opening in diameter at winter, approximately $5 \mathrm{~cm}$ and $6.3 \mathrm{~cm}$, respectively. What's the most important is that both of them varied greatly in diameter in the different seasons, for example, approximately $6.5 \mathrm{~cm}$ and $7.2 \mathrm{~cm}$ at spring.

Surface expansion coefficient of rumen. In yak, the surface expansion coefficient (SEF) of papillae in rumen mucosa was on average 5.95. The degree of size and density of papillae varied considerably in different regions, so the value of SEF was relatively large difference. For example, on the dorsal wall, even though the degree of density was not same in different individuals, the size of papillae was smaller in general, corresponding to the smallest SEF compared to other regions, was only 2.42 and the density of papillae was approximately $47 / \mathrm{cm}^{2}$. Comparing with the dorsal wall, however, the thick and full papillae were densely distributed on ventral wall, and the SEF was 9.62 at its maximum value. Although the height and diameter of some papillae on the floor of dorsocaudal blind sac even more than the dorsal wall's, the density is relatively sparse, only $55 / \mathrm{cm}^{2}$. Yet the SEF was greater than former, about 4.53. The density of papillae on the cranioventral floor of atrium was comparatively large but the shape was lower than ventral wall, and thence the density and SEF was about $71 / \mathrm{cm}^{2}$ and 7.23, respectively (Table I).

Table I. Gross measurement of the four stomachs of the yak $(\mathrm{n}=6)$.

\begin{tabular}{lc}
\hline Item & Mean \pm SD \\
\hline Weight of rumen $(\mathrm{kg})$ & $4.30 \pm 0.4$ \\
Weight of reticulum $(\mathrm{kg})$ & $0.52 \pm 0.1$ \\
Weight of omasum $(\mathrm{kg})$ & $0.61 \pm 0.1$ \\
Weight of abomasums $(\mathrm{kg})$ & $0.80 \pm 0.2$ \\
Total weight $(\mathrm{kg})$ & $6.23 \pm 0.5$ \\
Volume of rumen $(\mathrm{L})$ & $45.0 \pm 3.0$ \\
Volume of reticulum (L) & $3.5 \pm 0.5$ \\
Volume of omasum (L) & $4.1 \pm 0.6$ \\
Volume of abomasums (L) & $5.2 \pm 0.8$ \\
The SEF of DW & $2.42 \pm 0.1$ \\
The SEF of VW & $9.62 \pm 0.8$ \\
The SEF of DBF & $4.53 \pm 0.4$ \\
The SEF of ACF & $7.23 \pm 0.9$ \\
The papilla density of DW & $47.0 \pm 6.0$ \\
The papilla density of VW & $82.0 \pm 16.0$ \\
The papilla density of DBF & $55.0 \pm 7.0$ \\
The papilla density of ACF & $71.0 \pm 14.0$ \\
\hline
\end{tabular}

$\mathrm{DW}=$ Doral wall; $\mathrm{VW}=$ Ventral wall; $\mathrm{ACF}=$ Cranioventral floor of atrium; $\mathrm{DBF}=$ Floor of dorsocaudal blind sac.

Histology structure. The histology structure of the yak's four stomachs was basically same under the light microscopy, that is, following by mucosa, submucosa, muscularis and serosa. But the mucosa of forestomach belonged to nonglandular mucosa layer, only abomasum's mucosa layer had the glands.

Rumen cardia. The mucosa of the cardia in the rumen formed tiny and low papillae distributed sparsely, and was consisted of partly keratinized stratified squamous epithelium, which was composed of multi-layer cells varying in shape from upper to lower. A layer of basal cells near the basal membrane was low columnar, there were several layers of polygonal cells above basal layer, and then the flat cells, but the flat cells were partly keratinized on the outermost layer, where the cells with disappearing nuclei were dead, filling with keratin in the cytoplasm. As for shallow corneum, was yet homogeneous and the surface cells are constantly shedding (Fig. 1A). Deep cells, forming downwards a great many apophysis, were larger and went deep into lamina propria.

Lamina propria was mainly composed of loose connective tissue without glands, containing collagen fibers. Due largely to the submucosa composing of a thin layer of loose connective tissue as well, so there was no clear boundary between lamina propria and submucosa, where 


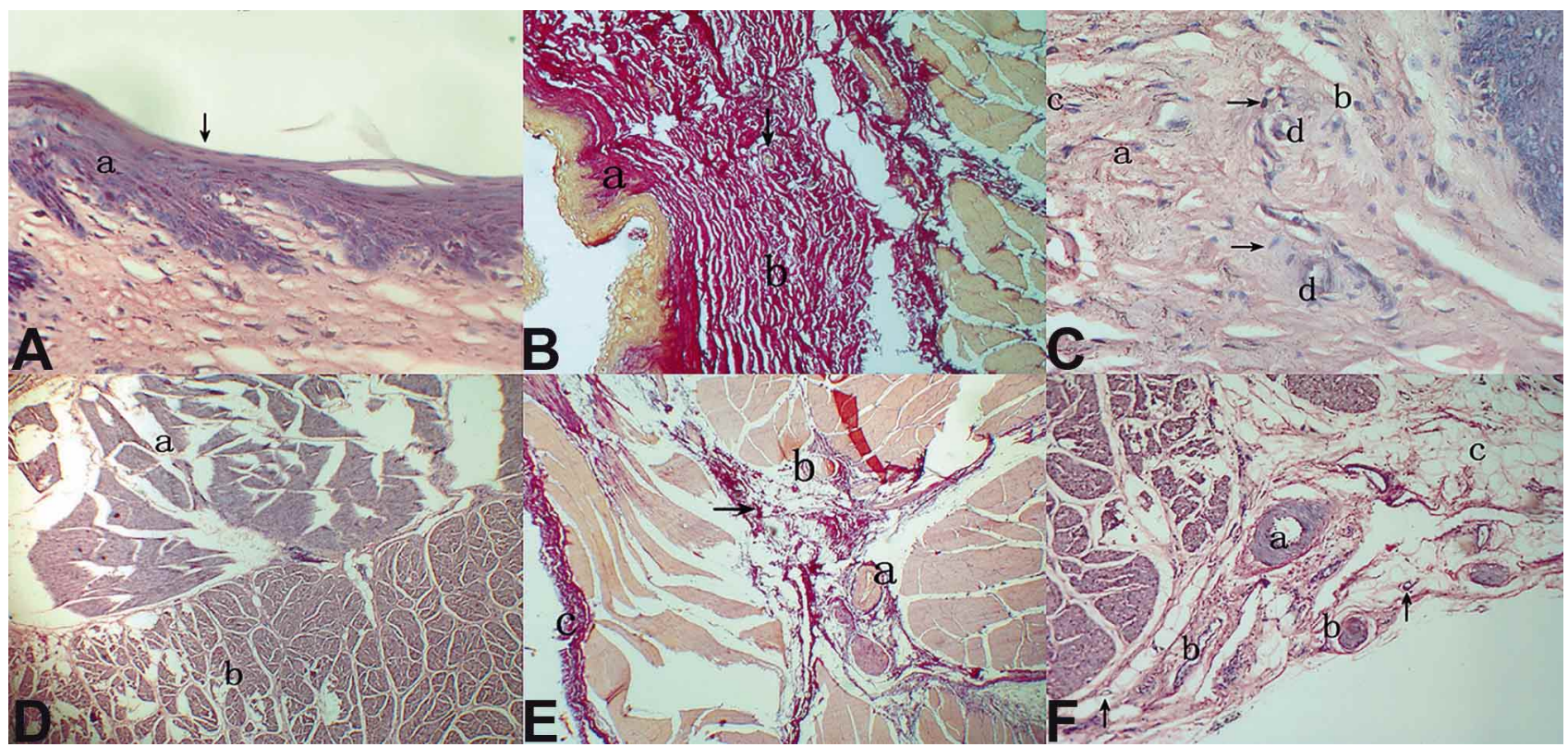

Fig. 1. Light microscopic view of rumen. (A) Stratified squamous epithelium (a) and squamous cell (arrow). HE X400. (B) Lamina propria (a) tunica submucosa (b) and capillary (arrow). Stained with elastic fiber X100. (C) Plasma cell (a) macrophage (b) fibroblast (c) lymphocyte (arrow) aorta (d) in lamina propria. HE X400. (D) Inner (a) and outer (b) muscle layer. HE X40. (E) Aorta (a) vein (b) collagen fiber (arrow)and chorion (c) in muscle layer. Stained with elastic fiber X40. (F) Aorta (a) vein (b) adipose tissue (c) and capillary (arrow) in tunica serosa. HE X100.

some plasma cells, macrophages, fibroblasts and mast cells can be observed (Fig. 1B). There were lymphatics and abundant veins and capillaries, but fewer arteries in smaller diameter in the loose connective tissue. Some large lymphocytes, which were easily stained by hematoxylin, were scattered in peripheral veins (Fig. 1C).

The muscularis was the thicker and included two layers of smooth muscle, the inner oblique muscle and the outer longitudinal muscle (Fig. 1D). The outer ring was about $1,551.8-1,622.3 \mu \mathrm{m}$ in the thickness, of which the muscle bundle was the more coarser than the inner. While the inner oblique muscle was only $1,237.1-1,521.7 \mu \mathrm{m}$. Veins and nerve plexus can be seen in connective tissue among muscle bundles. The muscle cells, cytoplasms of which were stained lightly, were slender fibrous in shape, with oblate nuclei located below the basal membrane. In addition, each muscle cell was wrapped by the endomysium (Fig. 1E).

The adventitia was composed of connective tissue. It was rich in collagen and elastic fibers, in which there were a great many blood vessels with the coarser diameter (Fig. $1 \mathrm{~F})$. For vein, the wall was collapsed and its flat lumen was also irregular in shape. For artery, the three-tier structure of wall was obvious. In addition, a large number of capillaries and lymph capillaries can be exhibited in the adventitia. There were abundant adipose tissue composed of a large number of fat cells near the muscularis. The nerve plexus, lymphocytes and fibroblasts distributed among connective tissue. What's the worth noting is that fibroblasts, which attached to collagen fibers with large nuclei stained lightly, were flat and its cytoplasm belonged to basophilic.

Table II. The average thickness of the wall of various layers of stomach (mm).

\begin{tabular}{lccccccc}
\hline \multirow{1}{*}{\multicolumn{1}{c}{ Section }} & \multicolumn{8}{c}{ The type of layer } \\
\cline { 2 - 8 } & & LP & MM & SU & MU & AD & The total of thickness \\
\hline Rumen cardia & 69 & 473 & - & - & 3,080 & 491 & 4,113 \\
Rumen vestibule & 90 & 320 & - & - & 2,834 & 610 & 3,854 \\
Ruminoreticular orifice & 90 & 512 & - & - & 3,508 & 161 & 4,271 \\
Reticulum & 65 & 1,080 & - & - & 3,850 & 245 & 5,240 \\
Sulcus reticuli & 103 & 166 & - & - & 6,400 & 1,790 & 8,459 \\
Reticuloomasal orifice & 110 & 270 & - & - & 4,380 & 1,100 & 6,356 \\
Omasum & 65 & 32 & 85 & 58 & 2,282 & 670 & 3,192 \\
\hline
\end{tabular}




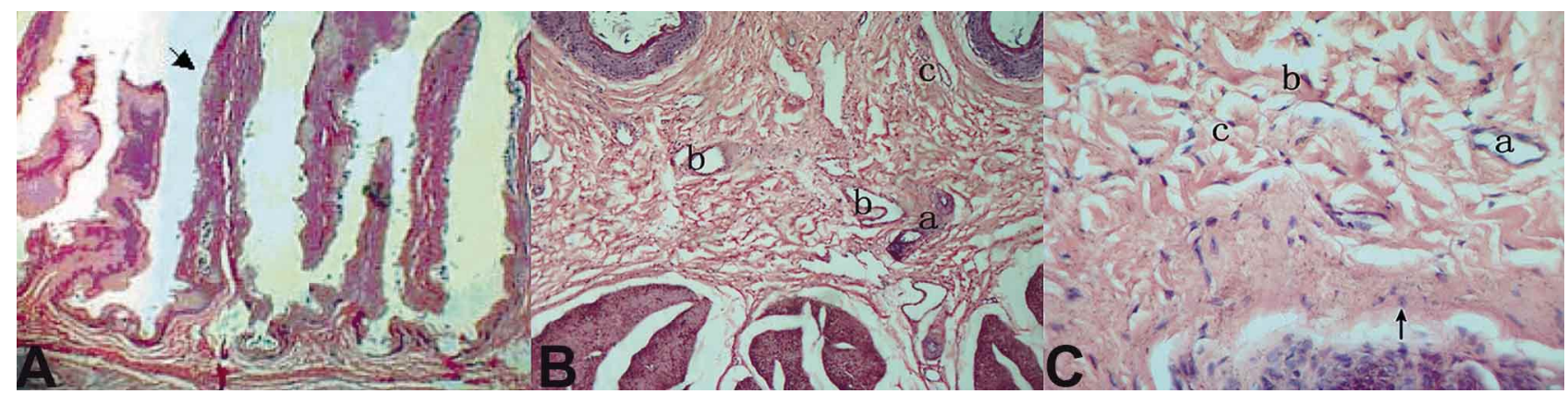

Fig. 2 Light microscopic view of atrium ruminis. (A) Papillae (arrow) of atrium ruminis. HE X40. (B) Aorta (a), vein (b) and capillary (c) in lamina propria and tunica submucosa. HE X100. (C) Plasma cell (arrow) fibroblast (b) lymphocyte (c) and vein (a) in connective tissues of lamina propria. HE X400.

Rumen vestibule. The surface of mucosa was covered with large and dense papillae, which were shaped like leaves, about 6,108.1-14,520.2 $\mu \mathrm{m}$ long (Fig. 2A). The mucosal epithelium was superficial keratinized stratified squamous epithelium. For the superficial keratinized layer, the shallow layer was composed of several layers of flat cells without nucleus, while the nucleus of cells in deep layer were flat spindle. The middle layer was composed of polygonal cells with round or oval nucleus. The basal layer was composed of low columnar cells with oval nucleus, which tightly packed and stained into blue-purple. The deep epithelium formed small protrusions extending to the lamina propria.

The lamina propria was composed of loose connective tissue without glands, and stretched papillae along the mucosal epithelium to form a continuous strip. Comparing with cardia, the lamina propria was relatively thin, containing small arteries, veins and capillaries (Fig. 2B). Fibroblasts attached to collagen fibers, irregular fusiform in shape, with blue-purple cytoplasm and oblate nucleus (Fig. 2C). The cytoplasm of plasma cells were abundant and were easily stained by hematoxylin. Interestingly, there was no muscularis mucosa. Submucosa, as loose connective tissue, was connected directly with the lamina propria without obvious boundaries. The fibers of submucosa contained collagen fibers and a small amount of elastic fibers, which were identified by the fiber dyeing. For example, the collagen fibers, which branched and interweaved network in form of waves, were pink. The fine elastic fibers mixed in collagen fibers yet were blue-purple.

The muscularis was more developed, including the inner row muscle and the outer longitudinal muscle, 1,236.0$1,786.5 \mu \mathrm{m}$ and $1,291.2-1,176.4 \mu \mathrm{m}$ in the thickness, respectively. Both of them were connected by the connective tissue. Although the structure of muscle was the same as cardia, the inner muscle bundle was the more coarser than the outer.

The adventitia was composed of loose connective tissue, in which lymphocytes, little veins, capillaries and fewer fat cells can be observed in light microscopy.

Ruminoreticular orifice. Mucosal epithelium of the ruminoreticular orifice possessed different histology structure. For example, long and dense papillae can be showed on the side of the rumen, by contrast, the papillae on the side of reticulum were shorter. Mucosal epithelium was keratinized stratified squamous epithelium, and the

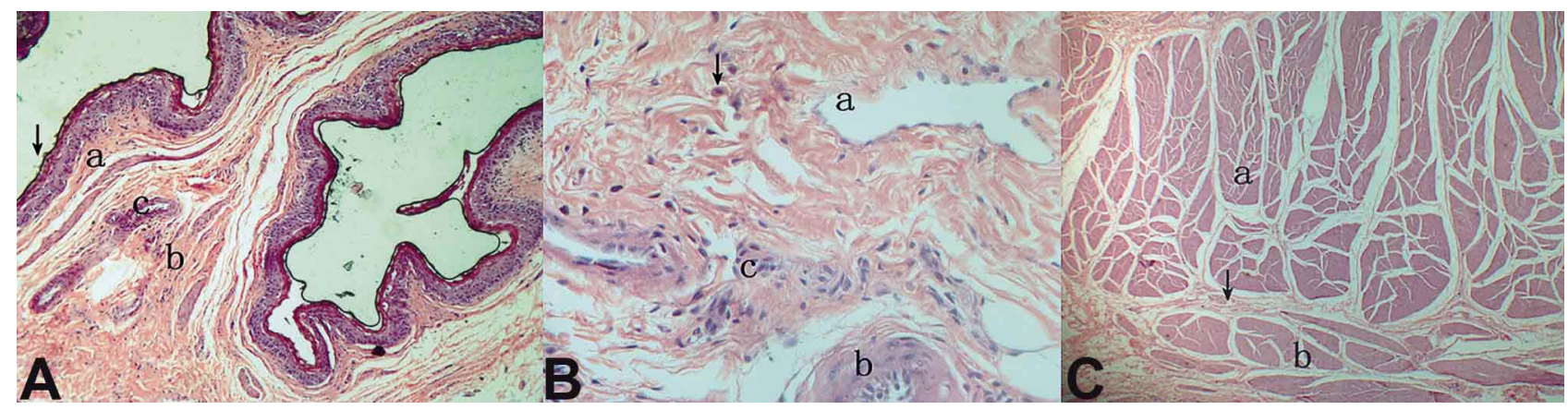

Fig. 3 Light microscopic view of ostium ruminoreticulare. (A) Stratified squamous epithelium (arrow) lamina propria (a) tunica muscularis (b) and blood vessel (c) of ostium ruminoreticulare. HE X100. (B) Aorta (b) and vein (a) macrophage ( $\downarrow$ ) and lymphocyte (c) in tunica submucosa. HE X400. (C) Inner (a) and outer (b) muscular layer and connective tissue arrow $\downarrow$ ) of ostium ruminoreticulare. HE X40. 
structure of cells in keratinized layer were the same as rumen cardia. The deep epithelium formed downwards a great many apophysis were small and went deep into lamina propria (Fig. 3A).

The lamina propria connected directly with submucosa due to no muscularis mucosa (Fig. 3B). There was no gland and was rich in collagen fibers in the lamina propria, in which a large number of scattered veins, arteries and capillaries can be obseved. The quantity and diameter of veins were more and larger than arteries. Furthermore, fibroblasts attached to the collagen fibers, plasma cells, lymphocytes and fewer macrophages in the connective tissue can also be observed clearly.

The muscularis was relatively thick, including the inner row muscle and the outer longitudinal muscle (Fig. 3C), 2,340.1-2,432.3 $\mu \mathrm{m}$ and $879.5-1,176.3 \mu \mathrm{m}$ in the thickness, respectively. Both of them were connected by the connective tissue, in which there were veins, capillaries and nerve plexus.

The adventitia was thin and composed of loose connective tissue, meanwhile, there were seldom veins and arteries. The outer layer was serosal.

Reticulum. The uplift plicae of mucosa in reticulum formed grids, which interconnected each other and became so-called small reticulum room with quadrilateral in shape. The keratinized papillae densely covered on the plicae and at the bottom of small room, the closer to sulcus reticuli and ruminal pleat, the smaller the reticulum rooms were, even disappearing (Fig. 4A). Mucosal epithelium was stratified squamous epithelium, which was not keratinized. The shape of cells in the surface, middle and basal layer were different, such as flat, irregular polygonal and cylindrical, respectively. In addition, the basal layer formed downwards a great many apophysis and went deep into lamina propria.

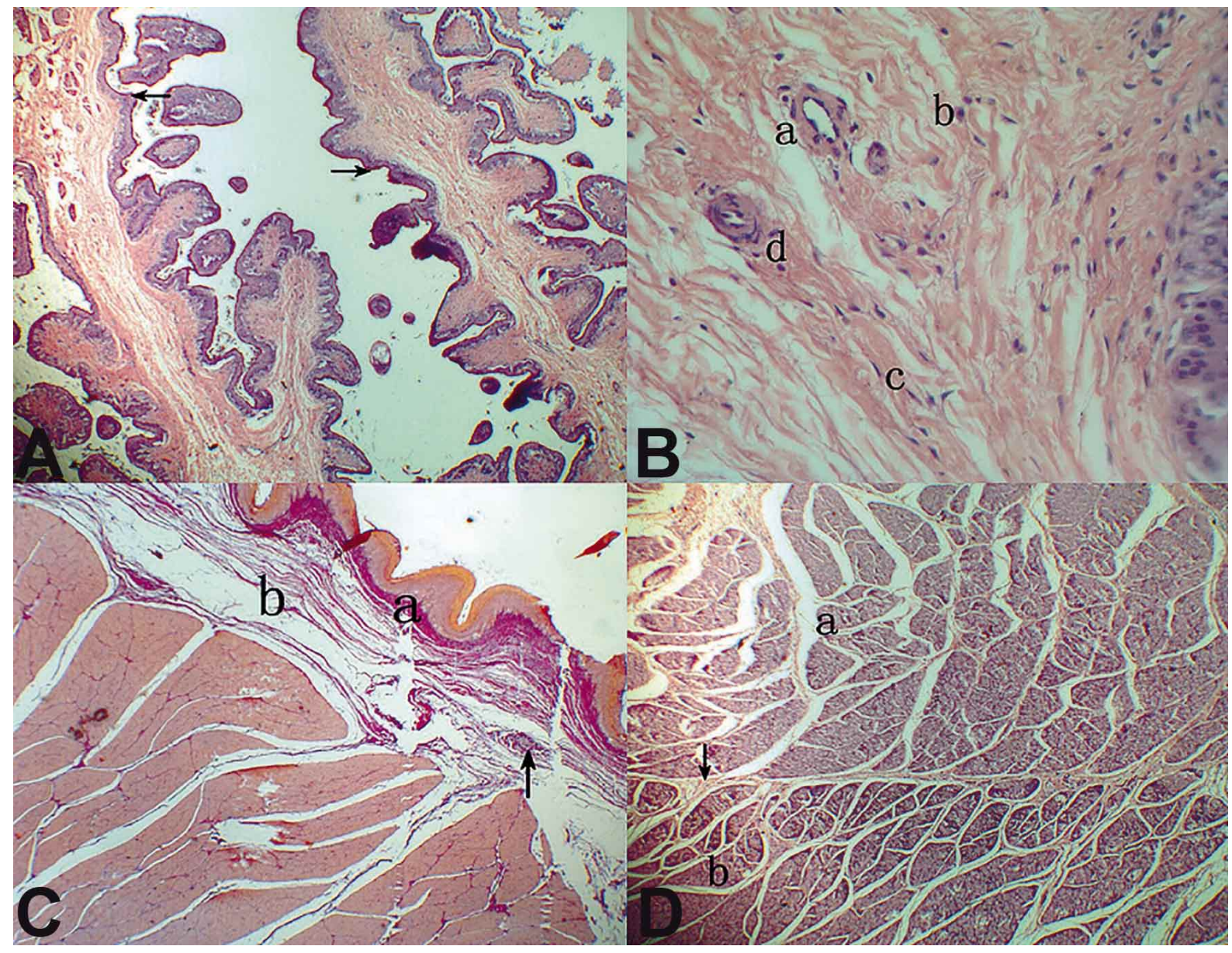

Fig. 4 Light microscopic view of reticulum. (A) Mucosal folds (arrow) of reticulum. HE X40. (B) Aorta (a) macrophage cell (b) fibroblast (c) and lymphocyte (d) in lamina propria. HE X400. (C) Lamina propria (a) tunica submucosa (b) and blood vessel (arrow) of reticulum. Stained with elastic fiber X40. (D) Inner (a) and outer (b) muscular layer andconnective tissue (arrow) of reticulum. HE X40. 
The lamina propria was composed of loose connective tissue, which contained abundant collagen fibers. And collagen fibers formed a continuous band in shape via going deep into papillae. Small veins, lymphatic vessels and capillaries can be seen in the loose connective tissue, in which fibers mixed with lymphocytes, fibroblasts, plasma cells and macrophages (Fig. 4B). There was no glands and muscularis mucosa in the lamina propria. The submucosa was composed of loose connective tissue, where collagen fibers were very thin and its branches interwove into a network. Although the submucosa connected the lamina propria, there was no obvious boundaries (Fig. 4C). Veins, capillaries, fibroblasts also can be observed easily in the submucosa. Fibroblasts with basophilic cytoplasm, which attached to the collagen fibers, were irregular cone.

The muscularis was more developed and composed of the inner row muscle and the outer longitudinal muscle, $1,537.4-2,369.9 \mu \mathrm{m}$ and $1,501.6-1,895.4 \mu \mathrm{m}$ in the thickness, respectively. Both of them were connected by the connective tissue, in which there were nerve plexus (Fig. 4D).

The adventitia constituted by a thin layer of loose connective tissue, which mostly contained elastic fibrous. There were abundant blood vessels and lymph capillaries in the adventitia, especially veins and capillaries, but less fat cells. The diameter of blood vessels were smaller than the submucosa's. The outer layer was serosal.

Sulcus reticuli. There was almost no papillae in the sulcus reticuli. And the epithelium was stratified squamous epithelium without keratinization (Fig. 5A).

The lamina propria, which was composed of loose connective tissue, was thin and connected with submucosa.
A small amount of veins, arteries, plasma cells and lymphocytes can be observed in the lamina propria.

The muscularis was very thick, including the inner oblique muscle and the outer row muscle. There were veins and arteries and lymphatic vessels in thick diameter between muscle bundles.

The adventitia was composed of loose connective tissue, about $751.4-1,840.7 \mu \mathrm{m}$ in the thickness. Intensive adipose tissue contained abundant fat cells can be exhibited toward the muscularis. In addition, there were also veins, arteries, less plasma cells and lymphocytes in loose connective tissue (Fig. 5B).

Reticuloomasal orifice. The plicae of mucosa in reticuloomasal orifice were gentle, so forming low papillae. The mucosal epithelium was stratified squamous epithelium. The surface of epithelium were flat and squamous cells, the middle were cubic cells, and the basal were columnar cells, which formed downwards a great many apophysis and went deep into lamina propria.

The lamina propria was composed of loose connective tissue without gland, where flat fibroblasts with many apophysis can be seen. The cytoplasm of plasma cells were abundant, with flat nucleus located in the partial side of cells. Occasionally, fewer veins and capillaries can be observed (Fig. 6A). Furthermore, there was no muscularis mucosa in the reticuloomasal orifice.

The submucosa and lamina propria were very thin and there was no boundary between them. But a lot of veins, arteries, capillaries and lymph capillaries in small diameter can be observed in them clearly.

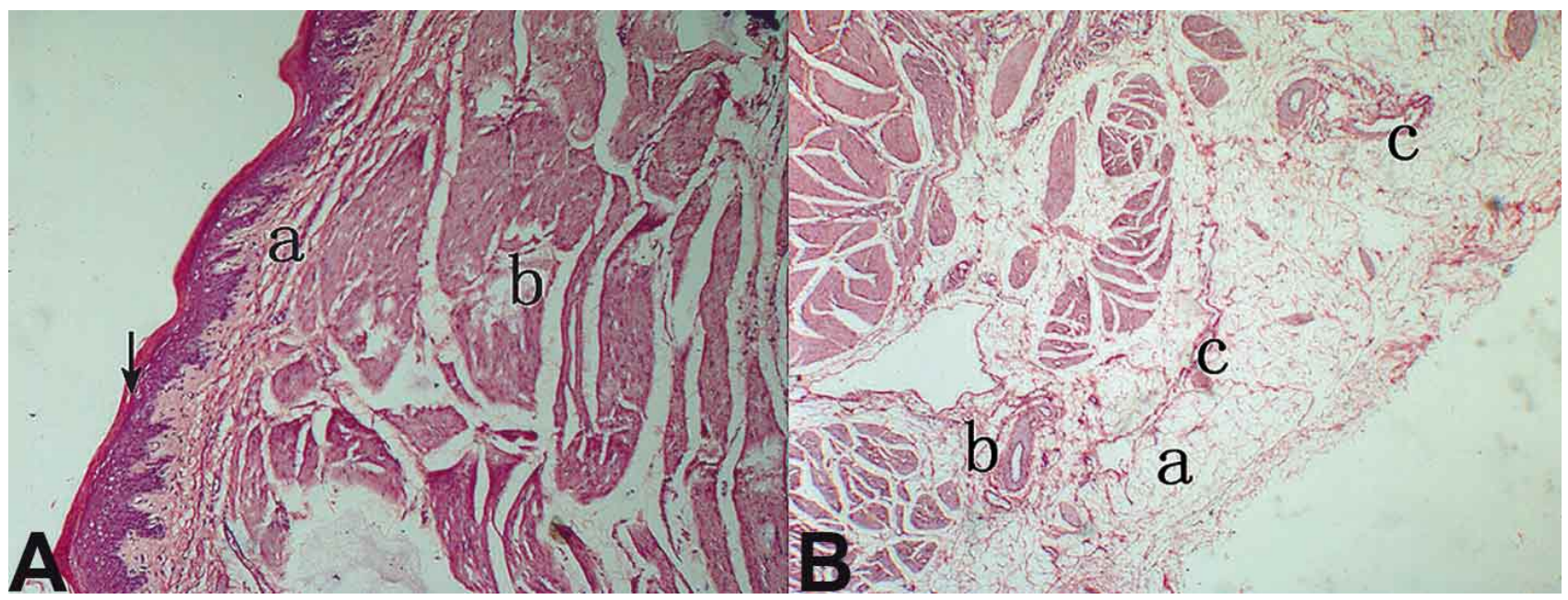

Fig. 5. Light microscopic view of sulcus reticulum. (A) Epithelium (arrow) submucous layer (a) and muscular layer (b) of sulcus reticulum. HE X100. (B) Adipose tissue (a) aorta (b) and vein (c) in adventitia. HE X40. 
The muscularis was very thick and belonged to striated muscle, including the inner row muscle and the outer longitudinal muscle, $982.3-1,880.9 \mu \mathrm{m}$ and 2,357.3-3,300.5 $\mathrm{mm}$ in the thickness, respectively (Fig. 6B). Both of them were connected by the connective tissue, in which nerve plexus, blood vessels and lymphatics can be exhibited occasionally. Myofibrils in the inner row muscle, which were wrapped by myolemma, were visible.

The adventitia was composed of loose connective tissue, about $820.8-1,269.3 \mu \mathrm{m}$ in the thickness. Abundant fat cells can be exhibited toward the muscularis. In addition, the thicker myofibrils interwove into a network, where a large number of lymphocytes, fibroblasts and plasma cells can be showed (Fig. 6C).

Omasum. The mucosa of omasum formed very special laminae omasi, both sides of which were covered with a lot of papillae. The developed muscularis mucosa, which were perpendicular each other in the direction, was located in both sides of the central muscle. There was also no gland in the mucosa. The mucosal epithelium of laminae omasi was stratified squamous epithelium (Fig. 7A), and the morphology of cells were the same as reticuloomasal orifice.

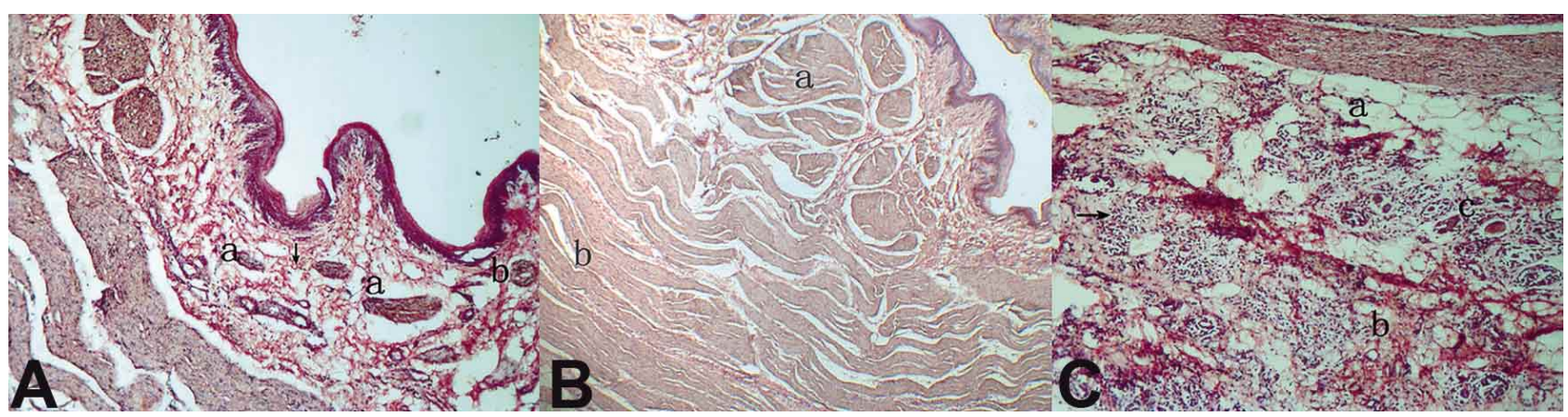

Fig. 6. Light microscopic view of ostium reticulo-omasicum. (A) Aorta (a) vein (b) and lymphocyte (arrow) in submucous layer. HE X100. (B) Inner (a) and outer (b) anmuscularis of ostium reticuol-omasicum. HE X40. (C) Adipose tissue (a) collagen fiber (b) blood vessel (c) and lymphocyte (arrow) of ostium reticulo-omasicum. HE X100.

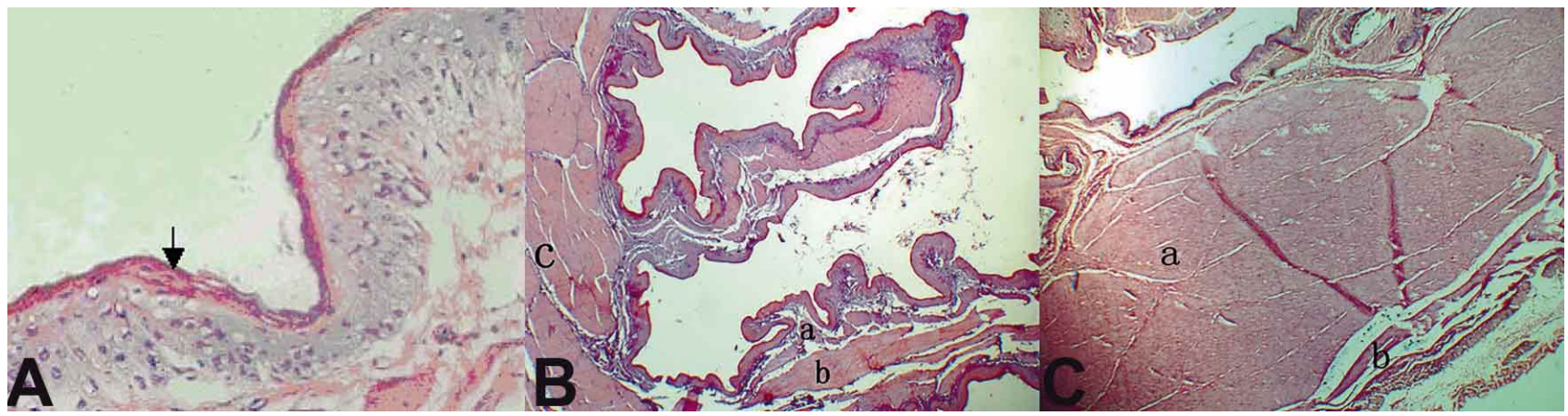

Fig. 7 Light microscopic view of omasum. (A) Stratified squamous epithelium (arrow) of omasum. HE X400. (B) Muscularis mucosa (a) central muscular layer (b) and muscular layer (c) of laminae omasi. Stained with elastic fiber X40. (C) Inner(a) and outer(b) muscular layer of omasum. HE X40.

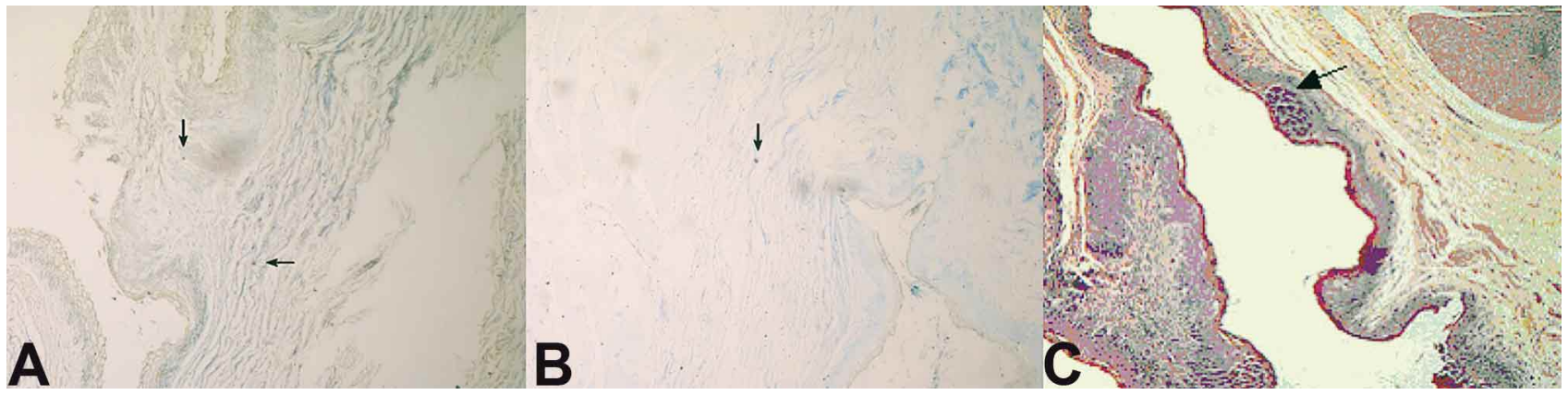

Fig. 8 Light microscopic view of distribution of lymphoid tissue in forestomach. (A) Mast cells (arrow) in lamina propria of rumen. Stained with toluidine blue X100. (B) Mast cells (arrow) in submucosa of rumen. Stained with toluidine blue X100. (C) Lymphoid nodule (arrow) in epithelium of ostium relicuto-omasicum. HE X100. 
The lamina propria was composed of loose connective tissue, where collagen fibers were thinner. And plasma cells scattered in the loose connective tissue. The smooth muscle fibers of muscularis mucosa constituted the bundle and formed a continuous layer along the lamina propria (Fig. 7B). The submucosa was very thin and composed of loose connective tissue, where the fine collagen fibers, veins and capillaries in smaller diameter can be seen. In addition, the fibroblasts, plasma cells and lymphocytes attached to the collagen fibers. The muscularis on the body of omasum included the inner row muscle and the outer longitudinal muscle, 1,717.2-2,025.6 $\mu \mathrm{m}$ and 288.9-309.7 $\mu \mathrm{m}$ in the thickness, respectively (Fig. 7C). Myofibrils in the inner row muscle were visible, and myocytes were elongated and flattened, with heavy stained nucleus. The adventitia was composed of loose connective tissue, where fibroblasts and lymphocytes mixed in the very thin collagen fibers, veins in thick diameter and abundant capillaries were visible as well. Fat cells can be exhibited toward the muscularis. In addition, the outer layer was serosal, during which scattered large lymphocytes in the dense and thick collagen fibers.

Distribution of lymphoid tissue in forestomach. The histological and histochemical observations on the rumen, the reticulum and omasum showed that lymphoid tissue was less, mostly scattered lymphocytes and plasma cells in the mucosa in stratified squamous epithelium. The mast cells can still be observed after toluidine blue staining (Fig. 8A and $\mathrm{B})$. In addition, dense lymphoid tissues varying in the size were distributed in the mucosa of rumen (Fig. 8C).

\section{DISCUSSION}

This study on histology and histochemistry showed that the forestomach wall of yak was the same as other ruminants, namely, mucosa, submucosa, muscularis and serosa (Ventura et al., 2013). The forestomach of yak was covered with stratified squamous epithelium. It was indicated that there was no muscularis mucosa in the rumen and reticulum by fibers staining, including collagen fibers and elastic fibers. However, this study found that the yak forestomach also had special structures in anatomy and histology.

The adjustment of the channels between substomachs in diameter was one of the ways to adapt the environment for ruminants (Ghoshal \& Bal, 1989). In order to ensure food to ferment, digest and absorb adequately in the rumen and reticulum, such as cattle and camel, the orifice between reticulum and omasum was relatively small and only allowed a certain standard size of food particles to pass
(Reid, 1985). In yak, the orifice between reticulum and omasum was significantly smaller than the orifice between omasum and abomasum in diameter, and the orifice of which was different in different seasons. There were abundant fibers and lignins in the food in the cold season, such as autumn and winter, in order to ensure food to be fully fermented in the rumen and reticulum, it is therefore explained that the orifice between reticulum and omasum was relatively small. But there were less fibers in the food in the warm season, such as Asteraceae and Ranunculaceae. So then food remained in the rumen for the shorter than in autumn and winter, thereby the orifice between reticulum and omasum became larger correspondingly.

The mucosal papillae in rumen, whose basic function was to absorb short-chain fatty acids, was closely related with the animal feeding in its structure. When the nutritional quality in food is high, a large number of nutrients were degraded into short-chain fatty acids by microorganisms in rumen, especially propionate and butyrate, which inhibited the formation of new mucosal papillae but stimulated the mitosis of epithelial cells of the stomach wall. Thus the more plicae and mesh membranes can be formed and increased the surface area of papillae. It expanded not only the surface area of original mucosa but also the absorption area in rumen. In accordance with the theory of Hofmann et al. (1972), the SEF value of rumen of concentrate selector was greater than roughage feeder. Prins \& Geelen (1971) studied the SEF values of other animals, such as red deer (Cervus elaphus), roe deer (Cupreolus capreolus) and catfish deer (Cervus dama). They thought that the concentrate selector and roughage feeder should be 7.0-9.5 and below 3.5, respectively (Hofmann et al., 1988; Demment et al., 1982). However, the SEF of the yak was 5.95 in winter, so the digest system of the yak has the characteristics of both concentrate selector and roughage feeder. Due to enough availability of food and those food containing high fiber in autumn and winter, it is therefore suggested the full fermented foods increased volatile organic acids, thereby stimulated the growth of papillae ofrumen. What is regrettable is that this paper only discussed the surface expansion coefficient of rumen from two seasons due to the limitation of seasons regarding collecting specimens, so the other seasons of the data should be added in the further experiment.

In the yak, the ligulate papillae were distributed on the surface of rumen mucosa, about $800-1,500 \mathrm{~mm}$ long. While length of papillae of adult red deer and gazelle was approximately $600-4,000 \mu \mathrm{m}, 760-1,300 \mu \mathrm{m}$, respectively (Prins \& Geelen). By contrast, the yak's rumen papillae was smaller than red deer but larger than gazelle, goats and sheep (Hoppe et al., 1977). 
Yak forestomach was covered with special protective epithelium-stratified squamous epithelium, which had the characteristic of abrasion resistance, especially keratinized stratified squamous epithelium. It is therefore believed that this structure helps to digest rough, hard, indigestible food and protect the mucous membrane of the stomach from mechanical damage. The connection between basement membrane and connective tissue was uneven due to the latter becoming papillae convex to epithelium. The strong ability of division and differentiation of the deepest basal cells constantly formed new cell to supplement shedding superficial cells. In addition, the capacity and wall of the rumen of the yak was larger and thicker than that of the cattle, respectively. The papillae were longer and more numerous, which made the stomach bear more foods and contributed to the fermentation of foods and absorption of nutrients, and these papillae can also provide microenvironment for microorganism. Furthermore, it was found that the muscle of the yak forestomach was well-developed, especially the inner muscle of rumen and reticulum, indicating that the well-developed muscularis apparently helped food mixing and digestion. By the staining of elastic fibers and collagen fibers, we conclude that there was no muscularis mucosa in the yak rumen and reticulum, similar to that which occured in other mammals such as cattle (Vivo et al.), camel (Abdel-Magied et al., 2003) and sheep (Franco et al., 1993, 2011). Whereas in reindeer they not only possessed muscularis mucosa in rumen, but also went deep into the papillae (Mathiesen et al., 2000). Yet, the yak omasum was provided with more developed muscularis mucosa, which was vertical in direction with the central muscle. It is therefore believed that the yak forestomach may have evolved those specific structural characteristics in response to the unique living environment and dietary habits impose on the Qinghai-Tibetan Plateau.

In conclusion, it was suggested that the morphological features of the yak forestomach, namely, the papillae of rumen, grid of reticulum and page of omasum and welldeveloped mucosa of keratinized stratified squamous epithelium, were adaptation to a various rangeland of the plateau, especially great seasonal variation in feed supply in the highland of the Qinghai-Tibetan Plateau environment, China (Long et al., 2004, 2005). These findings may also improve our understanding of metabolism-related diseases, thereby benefiting human health.

\section{ACKNOWLEDGEMENTS}

This work was financially supported by the International Cooperation Program of Gansu province, China (No.1011WCGA161) and National Natural Science Foundation of China (39300097).

WANG, J.; LI, H.; ZHANG, L.; ZHANG, Y.; YUE, M.; SHAO, B. \& WANG, J. Caracterización histomorfométrica del preestómago del Yak (Bos grunniens) en la meseta Qinghai-Tíbet. Int. J. Morphol., 32(3):871-881, 2014.

RESUMEN: Seis preestómagos de yaks (Bos grunniens) fueron estudiados mediante disección macroscópica y métodos histológicos. Se encontró que el preestómago del yak constaba de tres partes: rumen, retículo y omaso, compuestas de mucosa, submucosa, muscular y serosa. Además, el epitelio de la mucosa se conformó con epitelio escamoso estratificado, con parte de células cornificadas superficiales. En el rumen, la mucosa formó papilas linguladas que variaron en tamaño y forma. El retículo, consistió en una superficie epitelial que se invaginó en distinta medida en la lámina propia, conformando varias formas de pliegues, es decir, cuadrículas como pequeños cubículos. Además, existían muchos pliegues secundarios densamente cubiertos con papilas cornificadas. La característica más llamativa del omaso, fue formar láminas que variaron en longitud, con papilas cortas y ásperas distribuidas en ambos lados. Tomados en conjunto, no hubo glándulas dentro de la mucosa y la lámina propia del preestómago del yak, donde los tejidos linfoides difusos se pueden observar claramente. Por lo tanto, creemos que esas características estructurales específicas del preestómago del yak pudieron haber evolucionado en respuesta a las condiciones de vida únicas y hábitos dietéticos que se presentan en la meseta de Qinghai-Tíbet.

PALABRAS CLAVE: Bos grunniens; Preestómago; Histomorfométrico; Meseta Qinghai-Tibetan.

\section{REFERENCES}

Abdel-Magied, E. M. \& Taha, A. A. Morphological, morphometric and histochemical characterization of the gastric mucosa of the camel (Camelus dromedarius). Anat. Histol. Embryol., 32(1):42-7, 2003.
Clauss, M.; Hofmann, R. R.; Streich, W. J.; Fickel, J. \& Hummel, J. Convergence in the macroscopic anatomy of the reticulum in wild ruminant species of different feeding types and a new resulting hypothesis on reticular function. J. Zool., 281(1):26-38, 2010. 
Demment, M. W. The scaling of ruminoreticulum size with body weight in East African ungulates. Afr. J. Ecol., 20(1):43-7, 1982.

El-Gendy, S. A. A. \& Derbalah, A. Macroscopic and microscopic anatomy of the omasum of the Baladi goat. J. Biol. Sci., 10(7):596-607, 2010.

Franco, A.; Robina, A.; Regodón, S.; Vivo, J. M.; Masot, A. J. \& Redondo, E. Histomorphometric analysis of the reticulum of the sheep during development. Histol. Histopathol., 8(3):547$56,1993$.

Franco, A.; Masot, A. J. \& Redondo, E. Ontogenesis of the rumen: a comparative analysis of the Merino sheep and Iberian red deer. Anim. Sci. J., 82(1):107-16, 2011.

Franco, A.; Masot, J.; García, A. \& Redondo, E. Ontogenesis of the reticulum with special reference to neuroendocrine and glial cells: a comparative analysis of the Merino sheep and Iberian red deer. Anat. Histol. Embryol., 41(5):362-73, 2012.

Garcia, A.; Masot, J.; Franco, A.; Gázquez, A. \& Redondo, E. Histomorphometric and immunohistochemical study of the goat rumen during prenatal development. Anat. Rec. (Hoboken), 295(5):776-85, 2012.

Ghoshal, N. G. \& Bal, H. S. Comparative morphology of the stomach of some laboratory mammals. Lab. Anim., 23(1):219, 1989.

Hofmann, R. R.; Saber, A. S.; Pielowski, Z. \& Fruzinski, B. Comparative Morphological Investigations of Forest and Field Ecotypes of Roe Deer in Poland. Acta Theriol., 33(9):103-14, 1988.

Hofmann, R. R. \& Stewart, D. R. M. Grazer or browser: a classification based on the stomach-structure and feeding habits of East African ruminants. Mamm., 36(2):226-40, 1972.

Hoppe, P. P.; Qvortrup, S. A. \& Woodford, M. H. Rumen fermentation and food selection in East African sheep, goats, Thomson's gazelle, Grant's gazelle and impala. J. Agric. Sci., 89(1):129-35, 1977

Jerbi, H. \& Pérez, W. Gross Anatomy of the Stomach of the Cervus Elaphus barbarus. Int. J. Morphol., 31(2):388-91, 2013.

Long, R. J.; Apori, S. O.; Castro, F. B. \& Ørskov, E. R. Feed value of native forages of the Tibetan Plateau of China. Anim. Feed Sci. Technol.,80(2):101-13, 1999.

Long, R. J.; Dong, S. K.; Hu, Z. Z.; Shi, J. J.; Dong, Q. M. \& Han, $X$. T. Digestibility, nutrient balance and urinary purine derivative excretion in dry yak cows fed oat hay at different levels of intake. Livest. Prod. Sci., 88(1-2):27-32, 2004.

Long, R. J.; Dong, S. K.; Wei, X. H. \& Pu, X. P. The effect of supplementary feeds on the bodyweight of yaks in cold season. Livest. Prod. Sci., 93(3):197-204, 2005.
Mathiesen, S. D.; Haga, Ø. E.; Kaino, T. \& Tyler, N. J. C. Diet composition, rumen papillation and maintenance of carcass mass in female Norwegian reindeer (Rangifer tarandus tarandus) in winter. J. Zool., 251(1):129-38, 2000.

Prins, R. A. \& Geelen, M. J. H. Rumen characteristics of red deer, fallow deer, and roe deer. J. Wildl. Manag., 35(4):673-80, 1971.

Reid, C. S. W. The progress of solid feed residues through the rumino-reticulum: the ins and outs of particles. In: Baker, S. R.; Gawthorne, J. M.; Mackintosh, J. B. \& Purser, D. B. (Eds.). Ruminants physiology: concepts and consequences. Perth, University of Western Australia Press, 1985. pp.79-84.

Redondo, E.; Regodon, S.; Masot, A. J.; Franco, A. \& Lignereux, Y. The gastrin and CCK cells in the gastrointestinal tract of the sheep during development. A differential study. Rev. Med. Vet., 148(6):511-8, 1997.

Redondo, E.; Masot, J.; Garcia, A. \& Franco, A. Ontogenesis of the omasum: a comparative analysis of the Merino sheep and Iberian red deer. Histol. Histopathol., 26(9):1135-44, 2011.

Ventura, A.; do Nascimento, A. A.; dos Santos, M. A. J.; VieiraLopes, D. A.; Sales, A. \& Pinheiro, N. L. Histological Description of Morphogenesis of the Gastroesophageal Mucosa of Gallus gallus domesticus (Linnaeus, 1758). Int. J. Morphol., 31(4):1331-9, 2013.

Vivo, J. M.; Robina, A.; Regodón, S.; Guillén, M. T.; Franco, A. \& Mayoral, A. I. Histogenetic evolution of bovine gastric compartments during the prenatal period. Histol. Histopathol., 5(4):461-76, 1990.

Wang, J. L.; Lan, G.; Wang, G. X.; Li, H. Y. \& Xie, Z. M. Anatomical subdivisions of the stomach of the Bactrian camel (Camelus bactrianus). J. Morphol., 245(2):161-7, 2000.

\section{Correspondence to: \\ Jianlin Wang \\ Institute of Zoology \\ School of Life Science \\ Lanzhou University \\ Lanzhou 730000 Gansu \\ CHINA}

\section{Email: jlwang@|zu.edu.cn}

Received: 03-01-2014

Accepted: 23-06-2014 